\title{
Lunch Time at the Child Care Centre: Neoliberal Assemblages in Early Childhood Education
}

\section{Fikile Nxumalo, Veronica Pacini-Ketchabaw, Mary Caroline Rowan}

Abstract: In this article we interrogate neoliberal assemblages within the context of eating and feeding practices in early childhood education. We consider how neoliberal assemblages are enacted and created through multiple linkages between micro and macro regulations and policies, and everyday food routines. We attend to the embodied intensities, desires and affects that accompany these neoliberal formations. In particular, we are interested in making visible entanglements between particular situated neoliberal assemblages and racialization and neocolonialism. In our analysis, we consider how eating and food routines, situated within Inuit early childhood education, come to matter as instances of neoliberal encounters that merge with other discursive and material forces to create particular, situated and at times contradictory neoliberal assemblages that have colonizing and racializing effects on the capacities of certain bodies in certain spaces.

Key words: neoliberal assemblages, early childhood education, neocolonialism, Nunavik, food and neoliberalism, food and race

Six babies are sitting with two educators at a half-circle feeding table. In an indentation in the table's straight side, the educators sit on plastic chairs. Six yellow plastic baby seats, each occupied, have been inserted into evenly distributed spaces on the table's curved side. On the table's surface, in close proximity to the educators, sit six yellow melamine plates ladened with bitesized pieces of French toast. There is a spoon for each child, which the educators use to give a bite of food to one child before moving on to the next. One little boy stretches to reach a plate of food, but it rests beyond his grasp. He swishes his hand, extending his arm across the surface of the table, but he can't quite reach. He emits a little cry. A little girl extends her arms into the air, and it looks as though she will tug on her ear. Somebody coughs and the 
educator coos caringly as she puts the food into the child's mouth. Another boy claps his hands together; they sound briefly, mutedly, and then he pulls at his bib. One girl has a spoon in her hand; she stretches with the silver instrument attempting to reach the food on the plate, and the utensil is quickly removed. Speaking softly, an educator gently offers encouragement to the eaters as she moves, first picking up the spoon that is resting on the edge of the plate, then collecting a piece of French toast with the vessel and extending it to reach the child's mouth. Each child is fed, not in a linear way, but here and there. The room smells eggy with the bread. A banging sound resounds in the background-rat, tat, tat-and the feeding continues.

In this article, we analyze neoliberal rationalities and mentalities within the context of early childhood education. By attending to how neoliberal rationalities and mentalities work as rhizomatic, contradictory, and mobile assemblages, we crack open eating and feeding routines in Inuit early childhood education. By cracking them open, we mean that we make them function alongside neoliberalism and, more poignantly, in connection with racialization and neocolonization. By conceptualizing neoliberalism as assemblages, we avoid generalized explanations of neoliberalism as an overarching system or machinic totality that simply shapes subjects. In our analysis, we seek to create disruptions in this conceptualization by confronting neoliberalisms on their slippery territory, making visible the subjectivities they produce as they affectively impinge on possibilities for action [Read 2009]. The concept of the assemblage, drawing on Deleuze and Guattari [1987], infers the importance of both materiality and practice to social formations [Prince 2010: 172]. As a field of inquiry, assemblage stresses not structural hierarchy but an oblique point of entry into the asymmetrical unfolding of emerging milieus.... Assemblage highlights the situated interplay of motion and contingency, of technology and ethics, of opportunity and risk. The space of assemblage is the space of neoliberal intervention as well as its resolution of problems of governing and living [Ong 2007: 5]. The vignette we opened the paper with is an ordinary moment in a child care centre in Nunavik ${ }^{1}$; this scene can be viewed as an assemblage composed of babies, educators, plastic chairs, French toast, a table, spoons, childcare licensing regulations, and much more. In this paper we map the assemblage we call Lunch Time at the Child Care Centre as part of a larger assemblage that we call the Inuit early childhood education-food-eating assemblage within the geopolitical context of Nunavik. We use the concept of assemblage to describe some of the multiple, heterogeneous, and at times incongruent connections between the shifting social, economic, political, and material forces that come togeth-

1 Nunavik region occupies the northern third of the province of Quebec, Canada. Nunavik is historically an Inuit territory. 
er in the emergence of geopolitically and temporally situated formations of early childhood governance and surveillance ${ }^{2}$. Following Stewart [2007], we present the assemblage through a series of ordinary affects. That is, we attend to the intensities of certain encounters, to disparate connections, and to everyday sites and situations that link us to systems such as neoliberalism and neocolonialism. Mapping elements of the assemblage allows us to engage, later in the paper, with the links between neoliberalism, racialization, and neocolonialism. To this end, we elaborate on these concepts from a range of theoretical perspectives that emphasize non-representation, notably Indigenous, postcolonial, poststructural, and posthumanist theoretical groundings [Braidotti 2008; Jiwani 2006; Hayes-Conroy, Martin 2010; Ruffolo 2009; Stoler 2008]. The emphasis of this analysis is on the multiple linkages or interconnections between key elements of the assemblage and the effects produced by the intermingling of these elements within the geopolitical context of Nunavik and the broader context of the forces of neoliberalism, racialization, and neocolonialism.

Our intent in mapping elements of the Inuit early childhood educationfood-eating assemblage is to flesh out its disparate elements, to show its mobile, contradictory, rhizomatic character. As Malins [2004] suggests, we attempt to move away from meaning or signification toward the production of affects. We invite the reader to consider the workings of the assemblage with respect to the affects, technologies, bodies, flows, visualizations, and power relations that conjoin to both create and emerge from the assemblage [Markus, Saka 2006]. For instance, one might consider the ordering of bodies according to policies and practices that act, often in subtle and hidden ways, to inscribe, categorize, stabilize, and, simultaneously, open up particular subjectivities while privileging certain political, social, and economic systems or structures. The actants we concentrate on in mapping the assemblage include government regulations, practices, and many other discursive and material mechanisms of surveillance and control that attempt to affect specific early childhood eating arrangements and that act to affect and appropriate subjectivities [Haggerty, Ericson 2000; Patton 1994].

While we conceptualize and map key components of the Inuit early childhood education-food-eating assemblage in Nunavik, we recognize that the assemblage we map herein is a partial and selective conceptualization of immensely complex, intrinsically elusive, and constantly forming modes and technologies of control in the domain of early childhood care and education. While we argue that identifiable and describable spatially and temporally

2 There is a growing interest in Deleuze and Guattari's concept of assemblage in the field of early childhood education. For example, see Olsson [2009] and Lenz Taguchi [2009]. 
located components cohere to form the Inuit early childhood-food-eating assemblage, these components and their interrelations can never be fully mapped or represented. In our mapping, we see early childhood as more than the practices that occur within its confines. We map the assemblage rhizomatically, attending to elements that might seem unrelated to early childhood education.

Our discussion of the Inuit early childhood education-food-eating assemblage is strategic. We see food-eating practices as a central political issue; this view allows us to engage with power production from visceral-political perspectives [Hayes-Conroy, Hayes-Conroy 2008; Hayes-Conroy, Martin 2010; Probyn 2001; Whatmore 2002], with the emergence and workings of neoliberal rationalities [Guthman 2008], and with the circulations of neocolonialism at an intimate corporeal level [Slocum 2008, 2011]. As Whatmore [2006] notes, what makes food-eating practices interesting is the molten climate of relations between science and society, technology and democracy in which the knowledge practices of social and natural scientists, civil servants and corporate lawyers, NGOs and direct action groups, citizens and consumers rub up against one another in the event of all manner of knowledge controversies [265].

As Slocum [2008] notes, food-eating practices are "racial practices" that become manifested in "the production and marketing of certain plants, the location and quality of someone's land, ideas about 'good' food and the gathering of racially identified people around some vendors and vegetables but not others" [856-857]. At the market, for instance, Slocum continues, "bodies are not just inscribed by food practices; they are materially produced through what people buy, who they talk to, where they grow vegetables, as well as through phenotypic differences" [857]. As such, food-eating practices are intimately related to colonial enterprises.

Before we map the Inuit early childhood education-food-eating assemblage, we provide a brief historical, political, social, and economic description of its geopolitical context, Nunavik, to help the reader situate the ordinary affects that follow.

\section{The geopolitical context: Nunavik}

Because of its geopolitical and historical circumstances, Nunavik is a strategic location for the analysis of neoliberal assemblages. Historically an Inuit territory, Nunavik occupies the northern third of the province of Quebec. It is composed of 14 communities and a population of 11,000 [Duhaime 2008], of which 90 per cent are Inuit and speak Inuttitut as a mother tongue [Makivik Corporation 2008]. Significant colonial changes first came to the region at the turn of the twentieth century. Hudson's Bay company traders, in 
search of fox pelts, evoked an economic colonialism as the demand for furs diverted subsistence hunters to a pursuit of furs for trade [Gombay 2009]. The traders also brought alcohol, guns, flour, tea, and sugar. The impact of these changes became pronounced with the arrival of the Catholic and Anglican missionaries who, within a twenty-year period starting around 1910, converted the majority of the Inuit population to Christianity [Igloliorte n.d.]. The white fur traders and missionaries brought with them diseases, formerly unknown in the territory, that resulted in much sickness and death. As Igloliorte [n.d.] has detailed in her curatorial text concerning the Inuit residential school experience, seemingly overnight the Inuit populations were becoming concentrated into settlements, threatened by disease, and made dependent on trade goods. These changes ushered in a new era of the impoverishment of Inuit culture that, in the span of a few decades, would have devastating long-term consequences [2].

Up until the 1950s and into the 1960s, Inuit were self-sufficient and lived on the land. Change was underway, however. In 1939 the Supreme Court ruled that Inuit were to be recognized as Indians as provided for in Canada's founding constitutional document, the British North American Act, and would be subject to the Indian Act [Igloliorte n.d.]. In 1941 Inuit were assigned Eskimo (E) numbers and tags because Canadian government officials wanted to keep records about them and they found Inuit names to be difficult to say, spell, and manage [Bonesteel 2008]. By 1951 the Indian Act was amended to specifically exclude Inuit. According to Bonesteel [2008], this amendment "sought to ensure that Inuit remained distinct from First Nations in legislation and governance" [vi]. Since 1966, federal administration of Inuit affairs has been arranged through the Northern Administration Branch of Indian and Northern Affairs Canada. Responsibilities for areas such as health and education, which constitutionally fall within provincial jurisdiction, were transferred to the province of Quebec in 1970.

For millennia the Inuit and Cree of northern Quebec occupied an area totaling 410,000 square miles, or $60 \%$ of the province's total land mass. In 1976, the James Bay Northern Quebec Agreement was signed. The Cree and Inuit signatures on the document sealed an agreement whereby Aboriginal rights to the land were exchanged for $\$ 225$ million, the rights to only the land within the settlements and their surrounding vicinity, and fishing and hunting rights within a wider area. The rest of the area would become public land. This agreement came about as a direct result of the development of a large hydro project in the area. While the federal and provincial governments of the day touted it as a great achievement, the opposition challenged it, suggesting it was nothing more than a modern-day treaty similar to those signed in the 19th century [O'Neill 1977]. 
On May 9, 2011, the government of Quebec announced a multi-billion dollar economic strategy which is purported to benefit all Quebeckers. It is predicted that $\$ 162$ billion in revenues will be added to Quebec's gross domestic product over 25 years. Notably, the plan involves the development of eleven new mines and the construction of a deepwater port and a network of roads in Nunavik [Quebec 2011]. The plan proposes opening the currently pristine lands of Nunavik to corporate neoliberal forces; it prompts concerns about further destruction of Inuit traditional territories and peoples, their languages, cultures, practices, and ways of being.

\section{Embodying and unsettling the Inuit early childhood education-food-eating assemblage}

Our mapping of the Inuit early childhood education food-eating assemblage begins with the assemblage that opened the paper, which we call Lunch Time at the Child Care Centre. We now read this assemblage alongside other food-eating assemblages that can be read as a series of ordinary affects: The Inuk [Inuit] Child; Food Regulations in Inuit Child Care; Residential Schooling and the Denigration of Hunter Gatherers; Appropriating Indigenous Food-Eating Knowledges For Literacy; Hunger in Inuit Communities; Health Consequences of a Western Diet; Contemporary Ordinary Encounters; Food Injustice; The Nunavik Nutrition Program; Canada's Food Guide for First Nations, Inuit, and Métis; Hunting, Trapping, and Entrepreneurism; Kivalliq Arctic Foods; Chemical Contamination; and At Camp.

Through this mapping, we attend to the intensities of certain encounters, to disparate connections, and to everyday sites and situations that link the Inuit early childhood education-food-eating assemblage to systems such as neoliberalism and neocolonialism.

\section{The Inuk [Inuit] Child}

In 1990, the women of Inukjuak, Nunavik, participated in a radio phonein show held for the purpose of providing an understanding of the Inuk ${ }^{3}$ child to be used in the preface of a book about activities designed especially for use with young Inuit children living in Nunavik. The women expressed that northern children are special because they follow and learn Inuit traditions as they grow. Inuit children have their own culture that is unique. Inuit children are special because of the food they eat. Most of the time, In-

3 In the Inuttitut language, the word Inuk refers to one Inuit person while the word Inuit refers to more than two. 
uit children eat country food ${ }^{4}$ like caribou meat, fish, ptarmigan and others. These foods are eaten fresh, frozen or cooked. Inuit children are often fed at odd hours, when they are hungry. Northern children are frequently taken outdoors, which helps them adapt to the cold northern weather. Inuit children often go hunting with their families [Kativik Regional Government 1990: 5].

\section{Food regulations in Inuit child care}

While many authors write about the social, cultural, economic, and nutritional value of locally hunted food [Willows 2005; Duhaime, Chabot,Frechette, Robichaud, Proulx 2004; Lipski 2010], provincial childcare licensing regulations provide rules for the provision of food in the child care centre. For example:

Regulation 110: A childcare provider must, when providing meals and snacks to children, ensure that the meals and snacks comply with Canada's Food Guide published by Health Canada.

Regulation 112: A childcare provider other than a home childcare provider must post the weekly menu for consultation by the staff and parents and ensure that the meals and snacks served to the children conform to the menu. A home childcare provider must inform parents of the contents of the meals and snacks served to the children.

Regulation 113: All food prepared on or brought onto the premises must be kept and served by the childcare provider under sanitary conditions at the appropriate temperature [Éditeur officiel du Québec 2011].

These rules make it difficult for child care centres to serve raw fish and frozen caribou, foods that are prepared in ways basic to the traditional Inuit diet yet are foreign to the authors of the regulations.

In 2003, a review of regulations was held in Labrador [Rowan 2003]; it recommended dividing the regulation concerning food handling into two parts, one concerning commercially procured food and the other related to locally hunted meats, which the group suggested would read as follows: "Related to locally procured foods: that food handling, food handling facilities and the preparation of food at a child care service shall be in accordance with the traditions and customs of Inuit in the region" [Rowan, 2003: 11]. Nine years later, this recommendation has not been adopted. In the northern territories

4 The Inuit Cultural Online Resource (ICOR) defines country food as "the name that Inuit use to describe traditional foods. Country food are things like arctic char, seal meat, whale, caribou etc. Originally these foods were consumed for day to day survival. Eating what the land and sea provided." Retrieved from http://icor.ottawainuitchildrens. com/node/19 
of Nunavut, the North West Territories, and Nunatsiavut, health inspectors oversee the serving of certified food submitted to the rigours of commercial food inspection by inspectors located hundreds of miles away from small communities. This system and its attendant regulations effectively bar child care centres from accessing locally hunted food.

\section{Residential schooling and the denigration of Hunter Gatherers}

In 1955 residential schools were established in Nunavik, and non-Inuit teachers who spoke a foreign language unfamiliar to Inuit children came to the north to enact a federal policy of assimilation [Department of Indian Affairs and Northern Development 1990]. In that year less than 15 per cent of Inuit had attended school. Nine years later, in 1964, 75 per cent of Inuit children attended residential school [Igloliorte n.d.]. The schools taught a program designed for children in an urban industrial society. Children were removed from their families for months and whole years at a time, and Inuttitut language use was forbidden.

Alice Miller [1983] writes about "poisonous pedagogy", linking educational and colonizing projects. Miller points out that education can be used to control and undermine rather than to nourish and respect. She suggests that this kind of pedagogy results in lost potential and in psychological issues. Citing Miller, Brody [2001] argues that Indigenous peoples have been subjected to an extreme form of poisonous pedagogy. In 2008 the Prime Minister of Canada apologized to the Aboriginal people of Canada for the wrongs inflicted in the residential school system. However, the education system in Nunavik continues to be dysfunctional. In 2006, Statistics Canada reported that only 39.3 per cent of Inuit students completed high school, a figure that is half the 76.9 per cent completion rate of the non-Aboriginal population.

Brody exposes the depth of the problem with the colonial educational project in writing about the racism experienced by residential school children as they were taught that every aspect of their so-called primitive home life was wrong and their language, clothing, food, and spirituality were challenged and denigrated by the non-Inuit teachers. Brody [2001] writes: "The residential school was part of a process of ethnocide.... The intention was to stop people being who they were-to ensure that they could no longer live and think and occupy the land as hunter-gatherers. The new and modern nation-states make no room for hunter-gatherers" [189]. Brody continues: There are virtually no people in the world today who live purely as hunter-gatherers. Many kinds of colonial process have transformed peoples' economic lives, even in the remotest areas. Those who see themselves as hunter-gatherers, and are seen as such by their neighbours, may also 
be part-time labourers, do bits of farming, have domestic animals or rely on welfare payments and state pensions [5].

In Nunavik, as elsewhere around the world, the hunters and gatherers were silenced, their rights to their land not recognized, their knowledge and skills discredited.

\section{Appropriating indigenous food-eating knowledges for literacy}

A series of published Inuttitut-language books sit on the shelves of an Inuit early childhood education centre. The books lay out in print local stories and Inuit knowledges.

One of the books, Caribou [Puttayuk 2008], includes eight pictures and the following text:

- People go hunting for caribou.

- They cut caribou into pieces.

- Inuit eat caribou boiled, frozen, dried, and fried.

- Inuit make clothing from caribou skin; we make caribou skin parkas, kamiks, mittens, and snow pants.

- When the caribou are hungry, they eat grass.

- Caribou go swimming when they don't like mosquitoes.

- Caribou crouch to hide when they are tired.

- Inuit kill caribou for food and clothing.

Another of the books, Annie's Ulu, tells the story of a little girl who was always eating junk food. One day Annie decides to have arctic char, so she goes to the community freezer, gets a char, and brings it home. She leaves the char to thaw on the floor, but it is too frozen. She asks herself, "How am I going to cut the char? I need an ulu." Because there were no ulus at her house she goes to her grandmother's place. Annie borrows an ulu from her grandmother, returns home, cuts up the char, and eats it. The next day is Annie's birthday. She opens the present from her father and it is an ulu. Annie is so excited to receive an ulu that she says, "I will try my best to eat Inuk country food instead of junk food" [Taqulik 2008].

\section{Hunger in Inuit communities}

Colonialism includes three main facets: business, church, and state. Business came first to the north with the whalers, followed by the fur traders, starting in the 1600s. Brody [1975] explains the consequences: "It was trapping that broke Inuit self-reliance, trapping for the fur trade. Before the traders began demanding fox skin, that resource lay at the very edge of a hunter's life" [149]. The Hudson's Bay Company created an economic serfdom which led to hardship and which changed the purpose of hunting from harvesting food for family and community to trading with the corporation. It 
was after this shift that hunger became known. The hunter-gatherer lifestyle had insured food for most people most of the time; because resources were shared, people enjoyed a similar quality of life, which included ample leisure opportunities. Inuit had equal access to the land and its resources, and their society was based on egalitarian principles of mutuality, not hierarchical systems [Brody 2001]. This reality is in stark contrast to the current one where in 2008, the Aboriginal Peoples Survey reported that 24 per cent of Inuit children experience hunger every month [Statistics Canada 2008].

\section{Health consequences of a western diet}

Surveys of the Inuit populations in Nunavik were conducted in 1992 and again in 2004. Findings indicate that obesity prevalence among adults ages 18 to 74 had increased by 49 per cent-from 19 per cent to 28 per cent of the population [Nolin, Lamontagne, Tremblay 2007]. In a recent study, Chateau-Degat et al. [2010] link the increasing prevalence of obesity in Nunavik to decreased consumption of Inuit traditional country foods, which are rich in nutrients such as iron, B vitamins and omega- 3 fatty acids. This decrease in consumption of traditional foods has been accompanied by an increase in consumption of Western non-nutrient-dense foods [Hopping et al. 2010]. The prevalence of obesity has also been associated with several health challenges, including a doubling of the incidence of hypertension among Nunavik Inuit since the 1992 Nunavik Inuit health survey [Chateau-Degat et al. 2010].

\section{Contemporary ordinary encounters}

One of the authors of this article, Mary Caroline Rowan, spent two months in Nunavik this year conducting her graduate research in a child care centre [Rowan 2011]. She recalls how each evening group session began with a supper. On the last night of her stay, one of the participants brought frozen fish from Kangirsuk, which the group ate with frozen caribou meat from Inukjuak. During this final meal together, the group sat on the floor in a circle. A quiet peacefulness and engagement connected the group as they took great joy in sharing a meal of country food. This was in sharp contrast to our first meal which, although delicious and prepared by a local Inuk man trained as Cordon Bleu chef, consisted of store-bought beef, which we ate sitting on chairs at a table. A certified chef is not permitted to serve uncertified meat. This renders it impossible for him to work within the law and to purchase, prepare, and serve locally hunted meat.

Food injustice

Mary Simon, the president of Canada's national Inuit organization Inuit Tapiriit Kanatami delivered a talk entitled "Inuit and Social Justice" in July 
2011. Her speech focused on the gaps in living conditions and services between Inuit and southern Canadians. Simon noted: "Foods and commodities that supplement traditional country foods are staggeringly expensive" [2011: para.92]. A 2006 comparative study found the average cost of food in Nunavik to be 57 per cent more expensive than in Quebec City [Bernard 2006, as cited in Gombay 2009: 121]. The high cost of food in the north, combined with limited choice and compromised quality, keeps people from buying fresh fruits and vegetables [Willows 2005]. A new Nutrition North Program [not to be confused with the Nunavik Nutrition Program described below] launched by the federal government on April 1, 2011, sets out to reduce some of the costs of purchasing fresh food in Arctic communities.
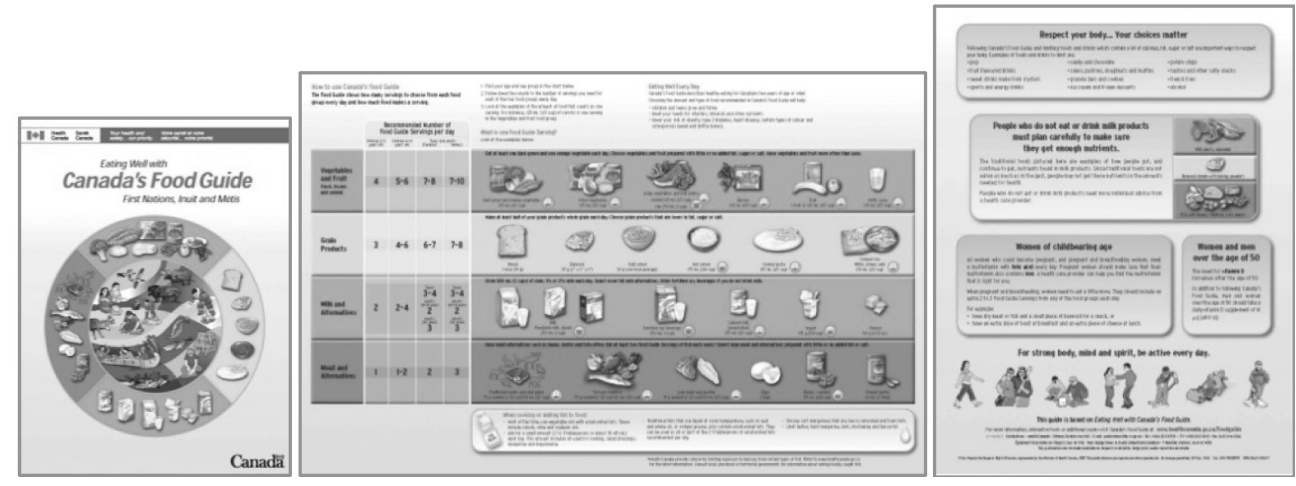

Figure 1: Canada's food guide for First Nations, Inuit, and Métis Source: Eating Well with Canada's Food Guide, Health Canada

\section{The Nunavik Nutrition Program}

The Nunavik Nutrition Program was launched in 2004 to address the effects of infant deficiency anemia [IDA], a preventable nutritional deficiency [Kativik Regional Government 2006]. Risk factors for IDA include drinking evaporated cow's milk, chronic infant sickness, and exclusive breastfeeding. The main concerns are that IDA affects motor, cognitive, and social-emotional development in young children. The levels of iron deficiency in First Nations and Inuit populations are significantly higher than those for the rest of the population [Christofides, Schauer, Zlotkin 2005: 597].

Kativik Regional Government and the Nunavik Board of Health and Social Services worked with a team from the University of Laval to develop menus for children in child care centres that included locally procured meats and fish. The team started with a review of the literature and then set out to analyze the nutritional value of country foods. The idea was that, by referencing Canada's Food Guide for First Nations, Inuit, and Métis and provid- 
ing the daily nutritional requirements, employing the nutritional strengths of country food, the effects of IDA could be addressed. The parent majority boards in every community in Nunavik adopted the nutrition policy that was created to guide the program. A broad base of support from the university, health board, regional government, and school board included cooks' training, educator training, and community visits. Early results showed a significant decline in IDA "with few anemic children" [Gagné, Vézina 2007]. One concern noted was that "infrastructure is needed to assure $a$ steady supply of country food" [Tagataga 2008: 17]. A study conducted concerning parents' perceptions of the Nunavik Nutrition Program (NP) found that "parents perceived that the NP is good for the health and the development of children. They raised the importance of ensuring regular consumption of country foods at daycare" [Dufour, Hamelin, Turgeon-O'Brien 2010: S 87]. Because many centres have had problems procuring locally hunted meats, the report recommended that "Inuit community members must find ways to ensure the regular supply of country foods at daycare" [S 87]. One source of country food is the Hunters and Trappers Association.

\section{Hunting, trapping, and entrepreneurism}

The Inuit Hunter Support Program was first laid out in 1975 under section 29 of the James Bay and Northern Quebec Agreement [Quebec Government 1998]. Its shape and scope, however, were only formally determined with the passage of provincial legislation in 1983 [Quebec Government 1982]. The program's objective is "to favour, encourage and perpetuate the hunting, fishing and trapping activities of the beneficiaries as a way of life and to guarantee Inuit communities a supply of the produce from such activities" [Quebec, Government 1982: 4]. Thus the program emphasizes the production and consumption of food as reflections of an Inuit way of life [Gombay 2009: 120].

Gombay [2009] underscores the role of the James Bay Northern Quebec Agreement in effecting major changes in Nunavik's economy. She describes Inuit societal prohibitions related to selling meat between people and tensions related to selling country food. She describes the Hunters and Trappers Association (HTA), which receives government funding, as a hybrid organization that functions in an in-between place, connecting the values of a sharing society with the operations of a market economy. Gombay does not reference the HTA's selling food to child care centres; in fact she details the way the organization pays hunters to hunt in a limited way, with the result that the payment acts more like a subsidy as it does not cover real costs. The food purchased from the hunters is then made available without charge to community members on an occasional basis. 
These hunters live contemporary (as opposed to traditional) lifestyles and they operate in a market economy, which requires substantial funding to purchase equipment. They also live and operate in a traditional economy and provide for their own families and extended families and friends according to Inuit food sharing values. It is interesting to consider how these systems coalesce in this process of cultural and societal change; these tensions may help to explain why it is hard for the centres to access and purchase country food.

\section{Kivalliq arctic foods ${ }^{5}$}

Kivalliq Arctic Foods (KAF), so named to "identify with Arctic foods and also to be market rather than product driven" [Meis Mason, Dana, Anderson 2007: 792] is a development company formed by the Nunavut Development Corporation [NDC], a Crown corporation of the government of Nunavut, to process arctic char and caribou meat for sale. KAF has federal approval to sell caribou throughout Canada and has export certification for the European Union and the USA [Meis Mason, Dana, Anderson 2007]. Describing KAF's marketing strategy, Meis Mason, Dana, and Anderson [2007] observe that the company created a website to increase its market and establish a stronger Inuit brand. The wording of the advertising stressed 'Quality', 'Land', 'Wild naturally', 'Truly wild' and 'Organic'. KAF reinforced that caribou eat lichens and willows not touched by pesticides. It also associated the product with the romance of the north.... Along with its name change, KAF changed its logo to use images associated with the Inuit-the northern star, inukshuk and igloo. At the trade shows, the KAF booth at the Aboriginal pavilion featured an Inuit employee wearing traditional styled Inuit clothing. As well, the northern star, inukshuk and igloo were prominently displayed in the background [798].

\section{Chemical contamination}

As Johansen [2002] writes, the Arctic, "which seems so clean on the surface", has become one of the most contaminated places on Earth-a place where Inuit mothers think twice before breast-feeding their babies because high levels of dioxins and other industrial chemicals are being detected in their breast milk and where a traditional diet of "country food" has become dangerous to the Inuit's health.... Native people whose diets consist largely

5 Kivalliq Arctic Foods is located in a northern territory outside Nunavik, on the west side of Hudson's Bay. A similar business initiative called Nunavik Arctic Foods which was formed to commoditize caribou meat from Nunavik was closed due to a lack of profitability [Fugmann, 2009]. 
of sea animals (whales, polar bears, fish, and seals) have been consuming a concentrated, toxic chemical cocktail [Figure 1].

Lipski [2010] writes about the "Arctic dilemma," that is, the health risks of persistent organic pollutants [POPs] and of mercury and lead in the food supply must be balanced with the nutritional, spiritual, cultural, and economic strengths associated with country food. She notes that the World Health Organization has called for locally and regionally appropriate food strategies given that people's health improves with the increased consumption of traditional foods. Duhaime et al. [2004] did a Nunavik-focused socioeconomic study concerning food contaminants and came to a similar conclusion. They considered the health hazards associated with contaminants, including effects on children's brain development. They presented arguments about country food and health and noted that the risks associated with pollutants balance out because imported foods are costly and are not a good substitute for locally hunted game and fish. These authors concluded with descriptions of how harvesting, sharing, processing, and eating are linked with spiritual well-being and identity. Willows [2005] notes the cultural importance of food, underlining how food is about much more than both nutrition and pollutants. She calls for research on the topic that extends the conversation beyond current epidemiological work.

\section{At camp}

Mary Caroline Rowan recalls an incident from a past visit to Nunavik: On the shores of Hudson's Bay, the hunters had returned with a seal. Our group gathered around the seal, sitting in a circle on the hard rock, to eat the food. The waves beat against the rocks while a light wind gently pushed. I sat beside a young mother who held an ulu in her hand; she cut a small piece of the fresh, raw, red meat. The seal had been cut down the middle and the intestines removed. The smell of fresh blood was pungent and my hands were red with blood. The mother placed the morsel of meat in her mouth and chewed it, then turned to her baby, removed the chewed food from her mouth, and placed it in her baby's mouth as she lovingly whispered "ababa" to her child. The baby cooed softly and easily swallowed the meat, then opened her mouth to her mother, looking for more.

\section{Framing neoliberal, racialized, and neocolonial assemblages}

Each of the assemblages described above can be seen as part of the Inuit early childhood education-food-eating assemblage within the geopolitical 
context of Nunavik. This assemblage functions as a "multiplicity of heterogeneous objects, whose unity comes solely from the fact that these items function together, that they 'work' together as a functional entity" [Patton 1994: 158, cited in Haggerty, Ericson 2000: 608]. Its elements "comprise discrete flows of an essentially limitless range of other phenomena such as people, signs, chemicals, knowledge and institutions" [608]. Through our mapping, we dug beneath the surface stability of Lunch Time at the Child Care Centre and cracked open the walls of the early childhood education classroom. We made these practices "encounter a host of different phenomena and processes working in concert" [Patton 1994: 158, cited in Haggerty, Ericson, 2000: 608].

We borrow the term assemblage from Deleuze and Guattari [1987] to highlight the multiplicity and contradictions that characterize the disparate assemblage of forces that act to control or surveil in the contexts of early childhood education classrooms in Nunavik with regards to food practices. These forces and the relations between them comprise lines of articulation or segmentarity, strata and territories; but also lines of flight, movements of deterritorialization and destratification. Comparative rates of flow on these lines produce phenomena of relative slowness and viscosity, or, on the contrary, of acceleration and rupture. All this, lines and measurable speeds, constitutes an assemblage [Deleuze, Guattari 1987: 3-4].

That is to say, the elements and effects of particular arrangements and locations of an assemblage are emergent, fluid, multiple, and, at times, contradictory [Hier 2003]. Conceptualizing an assemblage as emergent means to think of it as existing in tension. This includes the tensions between difference-repetition, fluidity-viscosity, relationality-divergence, stabilizationtransformation, and the mundane-extraordinary [Hier 2003]. Emergent neoliberal assemblages include the strengthening or coagulation of mutually constitutive forces and desires which give rise to, and sustain, neoliberal surveillance and governance, such as the desire for control, as well as potentials for disruption of surveillant forces, including desires for freedom and experimentation [Haggerty, Ericson 2000]. The emergence and sustainment of neoliberal surveillant forces in the assemblage is also marked by the coexistence and interaction of both synoptical forces and panoptical desires [Hier 2003: 406]. These surveillant forces and desires that constitute the surveillant assemblage are rhizomatic, operating through "variation and disjunction, intensification and horizontally fragmented expansion" [Hier 2003: 403].

These tensions allow for an interrogation of technologies of neoliberal surveillance as a site of collisions between striation and free flow; such an interrogation contributes to creating early childhood spaces that "capture, striate 
and appropriate flows" [Hier 2003: 402]. For instance, Inuit feeding practices are quickly captured, striated, and appropriated in the very instant they are written and used to enhance children's literacy, a Western conception. Indigenous feeding practices also become striated in the act of creating food regulations such as Canada's Food Guide for First Nations, Inuit, and Métis. These guidelines not only function as government regulations; more importantly, they protect and perpetuate the agriculture industry which often privileges commercial production and excludes traditional local hunting [Willett, Stampfer 2003]. Food regulations applied in child care centres also act as "a particular attempt to establish a certain order in food systems and organise human coexistence" [Hayes-Conroy, Martin 2010: 270]. Programs can also impact the chemical composition of human bodies. For example, the Nunavik Nutrition Program aims to ensure that children's minimum daily iron intake is met through foods eaten at the child care centre [Kativik Regional Government 2006].

Yet, these surveillant assemblages which entrap and appropriate bodies/ flows, redirecting and redefining them into a series of distinct flows that simultaneously support the forces of global neoliberal governance [Haggerty, Ericson 2000], exist alongside numerous possibilities for disruption and resistance [Ball 2005: 103]. We see these spaces of rupture and resistance in the potent and highly visceral encounters described in the Contemporary Ordinary Moments and At Camp assemblages above, where Inuit ways of knowing and being through food-eating encounters crack the striations of neoliberal and neocolonial governance. These contradictory movements create the rhizomatic character of surveillance assemblage. By making these movements visible, it is possible that our understanding of the difficulties in accessing locally hunted foods may be enhanced.

In bringing a critical lens to elements of surveillant assemblages in Nunavik's early childhood education food-eating practices, we are also mindful of the effects of particular configurations of technologies of control in early childhood in producing the individualist autonomous subject of neoliberal politics and global capitalism [Deleuze 1992]. This production can be witnessed in the Lunch Time feeding table encounter, and through food handling and safety regulations that may serve to undermine traditional approaches to food consumption, including eating raw meat.

\section{Neoliberalisms as mobile assemblages}

As noted above, we move away from making generalizations about neoliberalisms or from viewing neoliberalism as a static hegemonic ideology [Barnett 2009]. As such, we engage with an understanding of neoliberalisms as enacted through processes that are active at both the discursive and ma- 
terial levels, and that shape individual desirable embodied subjectivities. These processes function as a multiplicity of contingent, complex, mobile, and flexible assemblages. In other words, neoliberalisms possess repeated attributes that provide some unity or coherence, including the privileging of individual responsibility, and efficiency, and free market idealization [Clarke 2008]. However, these and other attributes emerge together with other contingent attributes in an unstable, mobile, incomplete, contradictory assemblage [Ong 2007]. The question we ask is What is happening; how are these assemblages acting in Nunavik?

We can consider, for instance, how Indigenous knowledges about hunting and eating traditional country foods circulate within neoliberal Inuit assemblages and become co-opted through their alignment with contradictory and divergent political, social, and material discourses and practices that are reconfigured within neoliberal power relations and other neoliberal assemblages [Clarke 2007; Ong 2007]. We can see such a dissonant alignment in Canada's Food Guide for First Nations, Inuit, and Métis, which includes traditional country foods, while Food Regulations in Inuit Child Care limit the possibilities for children's actual experiences with these foods. Through the alignments of the Hunters and Trappers Association and Kivalliq Arctic Foods with the marketization of Inuit hunting and food practices, we can begin to trace and make visible how, through strategic alignments, "universalizing trajectories of neoliberalism ... nonetheless always generate 'hybrid' assemblages" [Barnett 2009: 14].

We can also see, through the shifting material and discursive figurations of the caribou in the assemblages we have described, how neoliberal conditions include "extreme dynamism, mobility of practice, responsiveness to contingencies and strategic entanglements with politics" [Ong 2007: 3]. For example, in the Hunting, Trapping, and Entrepreneurism assemblage, the caribou emerges as both a marketized commodity and a symbol for neoliberal economic self-sufficiency. Within the contingencies of Inuit early childhood education, the caribou also emerges as a tool of neocolonial appropriation of cultural knowledge as described in the Appropriating Indigenous Food-Eating Knowledges For Literacy assemblage. The caribou also emerges as a symbol of neoliberal emphasis on free choice/self-determination in food-eating practices - sitting in dissonance with the Hunger in Inuit Communities assemblage and with neoliberal surveillance of obesity in the Health Consequences of a Western Diet assemblage.

\section{Neoliberalisms, Bodies, Subjectivities, and Affects}

We view the neoliberal subject not as a coherent subject but as a complex of affects, acts, and discursive-material relations, including influences of 
and interactions with neoliberal desires [Braidotti 2006]. Subjectivity is conceptualized as nomadic, never-complete, non-linear processes of multiple, dynamic, and often unpredictable experiential resonances and becomings [Braidotti 2008]. Bodies and their actions, perceptions, and affects interact with things, spaces, and discursive elements (including dominant discourses of culture, gender, and class) in the emergence of subjectivity as an embodied and embedded assemblage of multiple belongings that is made, remade, and potentially transformed in heterogeneous relational connections [Braidotti 1998; Deleuze, Guattari 1987; Gallacher, Gallagher 2008]. Through its mobility, contingency, and flexibility, neoliberalisms can "stick" together to produce dampening effects for the capacities of certain bodies and not others. For instance, we see the dampening effects produced by neoliberalisms in relation to colonial practices and processes of racializationeffects which may otherwise remain hidden by a predominant focus on the workings of neoliberalisms through macro/discursive processes of control or by simply addressing food-eating practices as an ordinary routine in an early childhood education classroom.

In mapping Lunch Time at the Child Care Centre alongside a wide array of disconnected but related assemblages, we might ask: How do neoliberal forces mobilize affective subjectivities such that certain bodies' capacities to act are dampened [Grosz 2002]? How are colonized and racialized subjectivities put to work through the circulation of the "mobile technologies" of neoliberalisms [Ong 2007]? What are some of the ways in which particular neoliberal ideas become taken-for-granted and normalized ways of understanding and being in the world in these particular contexts? What happens when bodies eat new and different foods, when the diet changes? What happens to bodies when they ingest and digest foods in new and different ways? What happens to bodies when individuals become embarrassed by what and how they eat? What happens to bodies when regulations prohibit the use of uncertified foods that would be hunted by local hunters, parents, grandparents, or siblings of children at the child care centre? What happens to bodies when the nutrition policy incorporates country food in menus created by nutritionists working within Euro-Western paradigms? What happens to bodies when food preparation takes place in a kitchen, behind a closed door?

\section{Neoliberalisms, freedom, and technologies of control}

Paradoxically, alongside the constraining effects of neoliberalism and its control of flows and constraints of bodies, neoliberal forces seem to expand possibilities. For example, individual choice and responsibility are shaped as desirable interests in Hunting, Trapping, and Entrepreneurism. Neoliber- 
al subjects thereby appear self-governing through the "freedom" to choose to act in particular ways and become responsible for their own acts. However, this very act of freedom "entails the establishment of limitations, controls, forms of coercion, and obligations" [Foucault 2008: 63, cited in Read 2009: 29]. Or, as Ong [2007] states, neoliberalism governs "through freedom [in ways that are] not uniformly applied to all groups and domains" within a specific context [4]. This apparent fluidity and capriciousness makes neoliberalism a slippery concept to pin down and creates challenges in effectively countering and disrupting neoliberal forces.

\section{Colonial debris}

It is difficult to conceptualize neoliberal assemblages without considering colonial histories. In the Canadian context, the effects of colonial histories continue to bleed into the present in many ways, particularly in the assimilation policies and ongoing material and cultural appropriations of Canada's First Peoples [de Finney 2010]. In early childhood education, we are ethically obliged to question the extent to which these neocolonialisms are perpetuated through policies and daily practices.

More generally, it is important to consider how histories act upon and shift present-day racisms and inequities. Even within current claims of a raceneutral and post-racial society, historical racisms remain and, in some cases, are reinforced and revitalized in new ways [Goldberg 2008]. For instance, interwoven into neoliberal policies and their expectations of individual responsibility is a tendency to ignore the important connections between past racist colonial violence and the racialized economic and political [dis]order that takes place today through chemical and health invasions related to environmental destruction [Stoler 2008]. Our intention in situating the Inuit early childhood education-food-eating assemblage within colonial enterprises is to engage in "confronting, challenging, and undoing the dominative and assimilative force[s] of colonialism as a historical and contemporary process" [De Lissevoy 2010: 280]. However, we painfully recognize that this undoing cannot be achieved by a single act, but is an ongoing and never-ending process given the mobility and contingency of neoliberal rationalities.

As we map the Inuit early childhood education-food-eating assemblage, we ask: How do racial and economic hierarchies and categories from colonial pasts endure, persist, and carry through in today's social, political, and material landscapes within the context of food-eating in Nunavik? How do contemporary food-eating practices figure Inuit people and livelihoods "to an anterior developmental space ... through which European and Europeanderived societies ordered a relationship to the nonhuman worlds" in ways that privilege nature/culture binaries [Anderson 2003: 422-423]? How are 
neoliberal colonialisms activated in Inuit early childhood education-foodeating practices and how do they shape its spatialities? For example, in reading Lunch Time at the Child Care Centre, we can ask: How are the tables, plastic chairs, metal spoons, and their configurations in the room all active participants in food-eating practices as neoliberal colonial acts? How might we reconsider the workings of neocolonialisms through food practices [Slocum 2011]? How do racisms and neocolonialisms emerge through where the food comes from that Inuit children in child care centres eat, through what food is made available, through the regulations pasted on the wall, and through how food itself is eaten [Slocum 2011]? How do neocolonial appropriations of cultural knowledge intersect with neoliberal forces of marketization of Inuit foods? How do colonial histories link with perceptions of particular racial configurations such that what is "already the past and that which is the present never quite seem to stay in place" [Schwarz 2000: 268]? What processes and outcomes of coloniality are manifest in the assemblage, and how are sociomaterial aspects of race mobilized in each encounter connected to systemic racism [Jiwani 2006; Subedi, Daza 2008, Swadener, Mutua 2008]? What happens when there is a significant disconnect between foodeating practices at home and at the child care centre? How do these processes perpetuate or disrupt forces of racism and colonialism?

Tracing how colonial histories matter to the present and how they may be mobilized in both political and relational processes in everyday life also provides the possibility to crack through the repetitions of race and racism-for new rearrangements and inventions that disrupt both the sedimentations of colonial racial legacies through biopolitical regimes and the emergence of "new racisms building on old exclusions" [Amin 2010: 6]. We are thus to seek ways to disrupt the force of stringent structural racisms and of histories repeating themselves in new ways, such as through hidden forms of governance disguised as freedom, patriotism, autonomy, and choice in relation to tools like Canada's Food Guide for First Nations, Inuit, and Métis, for example.

It is also important to attend to the "polyvalent mobilities" of race and racialization [Stoler 1995: 69] and to the limitations of painting the colonial past with a singular brush: Histories of oppression have been experienced differently by different people, and how they come to bear in encounters with difference cannot be known before hand [Amin 2010]. In other words, while it is important that we not dismiss colonialism as something that happened in the past nor minimize the force with which racist colonial legacies continue to impinge on the present, it is also important that we not reify colonialism's presence to a singular discourse and a singular impact on racialization. An alternative would be to view these effects as complex processes 
with varying resonances. The entrenched forces of racist colonial legacies collide with other material, affective, attitudinal, structural, discursive, and contextual forces in everyday relational encounters and have an impact on processes of subject formation-on each individual's capacity to act [Grosz 2005]. Our challenge is to make visible some of the many components in these assemblages and to consider the multifarious ways in which these forces act.

Neoliberalism "effectively masks racism through its value-laden moral project: camouflaging practices anchored in an apparent meritocracy, making possible a utopic vision of society that is non-racialized" [Roberts, Mahtani 2010: 253]. Thus a prevalent articulation of neoliberal assemblages is the emergence of a post-racial discourse that silences race through multiple discursive and material formations that infer that race is unimportant to individual economic success-success that is assumed to be unilaterally accessible. For example, by looking at Chemical Contamination of foods as an environmental issue, or by looking at the prevalence of infant anemia as a health issue in The Nunavik Nutrition Program, we can see how processes of racialization and neocolonialism are silenced and made invisible. This silencing effectively "relocate[es] racially coded ... disadvantage and reassign[s] identity-based biases to the private and personal spheres" [Davis 2007: 349], where each individual, with the exception of specifically targeted populations [in this case Inuit children in child care centres], needs to become responsible for his or her own diet. Through their entanglements with neoliberal discourses of individual responsibility and post-raciality, systemic racialized inequities are silenced and any lack of success is attributed to individual choices [Davis 2007; Roberts, Mahtani 2010; Shire 2008]. Racialized individuals unable to meet neoliberal economic and social demands are seen in binary opposition to those who have succeeded, when what should occur is an interrogation of the abrogation of state responsibilities by the privileging of the free market [Arat-Koç 2010]. The emergence of these individualized neoliberal subjectivities effectively occludes the convergence of histories and present-day constraints on how people can extricate themselves from the persistent racialized and neocolonial "order of things" [Stoler 2008: 193].

The capriciousness and contradictions of neoliberal assemblages also obscure racisms, not only through the discourse of post-raciality, but in certain contexts through a discourse of anti-racism, whereby anti-racism is a stated value, as in discourses of tolerance and inclusiveness. However, within these neoliberal assemblages, racialized inequalities are normalized and intensified by neoliberal policies [Goldberg 2008; Shire 2008]. We can consider how the use of Inuit dressed in traditional clothing to market tra- 
ditional foods in the Hunting, Trapping, and Entrepreneurism assemblage masks neoliberal alignments with systemic racialized inequities through a privatization or marketization of institutional racism whereby "racisms proliferate in the reductive impossibility of being recognized as precisely racist ... building silently on the structural conditions of racism while evaporating the very categories of their recognizability" [Goldberg 2008: 1715]. The persistence of racisms that limit the capacities of certain bodies appears to contradict neoliberal discourses of equal opportunity, freedom, or free agency. These contradictions of neoliberal formations, including the shifting and contradictory ways in which race comes to matter within neoliberal assemblages, make it difficult to ascertain neoliberalism's role as an active participant in the mobilization and sedimentation of racisms.

In Canada, the politics of recognition embedded in diversity and inclusion discourses strengthen the force of neoliberal assemblages by foregrounding the liberal rhetoric of freedom and equality, obfuscating the neocolonial inequities produced and required by neoliberalism, and shifting discussions of the everyday socioeconomics of racism and neocoloniality out of the political discourse [Lee 2010]. When viewed within their entanglements with neoliberal regimes, discourses of tolerance of diversity can be seen as a form of governance intended to manage Indigenous populations through the bestowing of rights under the general categories of "culture" and their normalizing expectations [Amin 2010; Pacini-Ketchabaw 2007]. We see this through the inclusion of country foods in Canada's Food Guide for First Nations, Inuit, and Métis while the difficulties in obtaining this food and its subjection to the forces of neocolonial appropriation are obscured. Within the discourses of acceptance of diversity, neocolonialisms in early childhood education remain largely unaddressed, as does the contingent, contextual, ambiguous, and hybrid emergence of cultural difference-in opposition to its essentialized and static representation in dominant imagery in early childhood education literacy pedagogies [James 2005; Pacini-Ketchabaw 2007]. Further, neoliberal child care systems work within rigid regulatory frameworks, yet neoliberal practices of "flexibility", "openness", and "tolerance of diversity" mask the governance of racialized Indigenous children, mobilizing and repeating racializations "with every outwardly progressive gesture, which works to normalize" through their dismissal as an insignificant factor in everyday life [Pacini-Ketchabaw 2007; Roberts, Mahtani 2010: 254]. Contrary to an appearance of neutrality, these progressive gestures of inclusion and tolerance are intensely racialized [Roberts, Mahtani 2010]. The entanglements of neoliberal assemblages with racism are made even more difficult to ascertain by the mobilities, complexities, and contingencies of race and racisms themselves. Race and racisms are not static entities; 
they continuously shift and take on new forms as they emerge within sociomaterial assemblages, even those disguised as anti-racist [Saldanha 2006].

\section{Confronting neoliberalisms and neocolonialisms}

By emphasizing the mobility and contingency of neoliberalism, we have paid attention in this paper to practices, regulations, discursive-material encounters, and affects that come together in multiple, fluid ways, including the "disjointed, disjunctured articulations" [Kingfisher 2002, cited in Clarke 2008: 142] in which neoliberalisms are expressed. Thinking through the Inuit early childhood education-food-eating assemblage, we highlighted the contradictory and capricious ways in which neoliberalism can present itself in Inuit early childhood spaces through a multiplicity of processes, regulations, and actions.

In our theorizing of neoliberal assemblages, we also found it critical to make visible possible connecting threads between the potential for racialization in everyday food-eating practices and the complex and contingent intersections with continuing colonialisms and neoliberalism. We made visible some of the cracks in the veneer of a dissonance between neoliberalism and racialization. This included a critical consideration not only of the connection between racialized discourses and the daily social, economic, and political realities of children's lives, but also how the affective dimensions of colonialism and neoliberalism are materialized in everyday processes of becoming subjectified. We suggested that neoliberal racial formations and the accompanying racialization of certain bodies emerge in multiple spatially and temporally contingent ways. However, the hybrid associations between neoliberalism and race suggest a sticky connection whereby "neoliberalism (its underlying philosophy) is fundamentally raced and ... works to modify the ways race functions" [Roberts, Mahtani 2010: 248]. In paying attention to these material and discursive remnants of racisms and colonialisms, we began to create ways to confront them and rearrange them into something different.

The rhizomatic ways in which the Inuit early childhood education-foodeating assemblage works creates continuous mechanisms of control, but at the same time it produces flexible, mobile, and self-regulating bodies [Deleuze 1992; Ruffolo 2009]. Importantly, rather than being conceptualized as distinct sites, these diffuse yet resilient environments of control consist of several surveillant assemblages within themselves, and they continually form rhizomatic connections with other materials, practices, bodies, and discourses, creating an expansion of surveillant assemblages [Haggerty, Ericson 2000]. Mar and Anderson [2010] explain this process further: As- 
semblages are not completed or stable constructions ... they are better conceived as temporary and provisional connective arrangements whose elements could be 'detached from it and plugged into different assemblages in which their interactions are different.... Possibilities always exist, not only for the failure of elements to come into alignment, but for the formation of other assemblages [37].

The understandings of neoliberalism we outlined above suggest an analysis oriented toward understanding the assemblage of everyday acts or encounters and their interrelationships with objects, practices, discourses, and policies. That is to say, borrowing from Deleuze and Guattari [1987], we attempted to map the hybrid molecular formations of neoliberalisms rather than view neoliberalism solely as a dominant molar configuration [Clarke 2008; Michelsen 2009]. Michelsen [2009] writes that "a 'molecular politics' or schizo-engagement offers avenues for productively engaging the complex dynamics of embodied desire that drive specific mobilization" [454] of neoliberal forces. Through a focus on the molecular, we began to trace how neoliberalism's far-reaching effects appropriate bodies and shape their practices. We also mapped how they capture and redirect flows, including "the capacity to communicate, to feel, to create, to think [towards] productive powers for capital .... [whereby] subjectivity itself becomes productive" [Read 2009: 33]. In this way, our hope is that we may begin to see how neoliberalisms form assemblages that continually capture and recapture early childhood practices. By reaching beyond discursive processes to create affects at the level of bodies, subjectivities, and potentials for bodies to act, affect, and be affected, we hope to transform, as Barnett [2009: 14] suggests, the relationships that subjects have with themselves.

\section{References}

Amin, A. 2010. The Remainders of Race. In Theory, Culture \& Society, 27 (1): 1-23. Anderson, K. 2003. White Natures: Sydney's Royal Agricultural Show in Post-Humanist Perspective. In Transactions Institute of British Geographers Ns 28: 422-441.

Arat-Koç, S. 2010. New Whiteness(Es), Beyond the Colour Line? Assessing the Contradictions and Complexities of "Whiteness" in the (Geo)Political Economy of Capitalist Globalism. In Razack, S., Smith, M., Thobani, S. (Eds.). States of Race: Critical Race Feminism for the $21^{\text {st }}$ Century. Toronto, On: Between the Lines, 147-168.

Ball, K. 2005. Organization, Surveillance and the Body: Towards a Politics of Resistance. In Organization, 12 (1): 89-108.

Barnett, C. 2009. Publics and Markets: What's Wrong With Neoliberalism? In Smith, S. Pain, R., Marston, S., Jones Iii, J.P. (Eds.). The Sage Handbook of Social Geography. London, Uk: Sage, 269-296. 
Bonesteel, S. 2008. Canada's Relationship With Inuit: A History of Policy and Program Development. Ottawa, On: Ministry of Indian and Northern Affairs.

Braidotti, R. 1998. Difference, Diversity and Nomadic Subjectivity. [online], <http:// www.translatum.gr/forum/index.php?topic=14317.0>

Braidotti, R. 2006. Transpositions: On Nomadic Ethics. Cambridge, Uk: Polity Press.

Braidotti, R. 2008. Of Poststructuralist Ethics and Nomadic Subjects. In Düwell, M. Rehmann-Sutter, C., Mieth, D. (Eds.). The Contingent Nature of Life Netherlands: Springer, 25-36.

Brody, H. 1975. The People's Land: Eskimos and Whites in the Eastern Arctic. Middlesex, Uk: Penguin.

Brody, H. 2001. The Other Side of Eden: Hunter-Gatherers, Farmers and the Shaping of the World. London, Uk: Faber \& Faber.

Chateau-Degat M.L., Dewailly, E., Noël, M., Valera, B., Ferland, A., Counil, E., Poirier, P., Egeland, G.M. 2010. Hypertension Among the Inuit From Nunavik: Should We Expect an Increase Because of Obesity? In Int. J. Circumpolar Health, 69 (4): 361372 .

Christofides, A, Schauer, C., Zlotkin, S.H. 2005. Iron Deficiency Anemia Among Children: Addressing a Global Public Health Problem Within a Canadian Context. In Paediatric Child Health, 10 (10): 597-601.

Clarke, J. 2008. Living With/In and Without Neoliberalism. In Focaal - European Journal of Anthropology, 51: 135-147.

Davis, D-A. 2007. Narrating the Mute: Racializing and Racism In A Neoliberal Moment. In Souls, 9 (4): 346-360.

De Finney, S. (2010). "We Just Don’t Know Each Other”: Racialized Girls Negotiate Mediated Multiculturalism In A Less Diverse Canadian City. In Journal of Intercultural Studies, 31 (5): 471-487.

De Lissevoy, N. 2010. Decolonial Pedagogy and the Ethics of the Global. In Discourse: Studies In the Cultural Politics of Education, 31 (3): 279-293.

Deleuze, G. 1992. Postscript on the Societies of Control. In Organisational Studies, $59,37$.

Deleuze, G., Guattari, F. 1987. A Thousand Plateaus: Capitalism and Schizophrenia. Minneapolis, Mn: University of Minnesota Press.

Department of Indian Affairs and Northern Development. 1990. Inuit. Ottawa, On: Minister of Supply and Services Canada.

Dufour, A.B., Hamelin, A-M., Turgeon-O’brien, H. 2010. Inuit Parents' Perceptions of the Nutrition Program in Nunavik Daycare Centers, Canada. In Journal of Nutrition Education and Behavior, 42 (4, Supplement 1): S86-S87.

Duhaime, G. 2008. Socio-Economic Profile of Nunavik, 2008 Edition. Canadian Research Chair in Comparative Aboriginal Condition. Québec, Qc: Université Laval.

Duhaime, G., Chabot, M., Frechette, P., Robichaud, V., Proulx, S. 2004. The Impact of Dietary Changes Among the Inuit of Nunavik (Canada): A Socioeconomic Assess- 
ment of Possible Public Health Recommendations Dealing with Food Contamination. Risk Analysis, 24 (4): 1007-1018.

Éditeur Officiel Du Québec. 2011. Educational Childcare Regulation: Educational Child Care Act [R.S.Q. C. S-4.1.1, S. 106]. Government of Quebec. [online], <http:// www2.publicationsduquebec.gouv.qc.ca>

Foucault, M. 2008. The Birth of Biopolitics: Lectures at the Collège De France, 19781979, Trans. Graham Burchell. New York, Ny: Palgrave Macmillan.

Fugmann, G. 2009. Development Corporations in the Canadian North - Examples for Economic Grassroots Initiatives Among the Inuit. In Erdkunde, 63 (1): 69-79.

Gagné, D., Vézina, C. 2007. Impact Study of Nutrition Program in the Child Care Centres of Nunavik. Powerpoint Presentation, Laval University, Groupe De Recherché En Nutrition Publique [Genup] and Public Health Research Unit Chul - Chuq.

Gallacher, L. A., Gallagher, M. 2008. Methodological Immaturity in Childhood Research? In Childhood, 15 (4): 499-516.

Goldberg, D. T. 2008. Racisms Without Racism. In Publications of the Modern Language Association of America, 123 (5): 1712-1716.

Gombay, N. 2009. Sharing or Commoditizing? A Discussion of Some of the SocioEconomic Implications of Nunavik's Hunter Support Program. In Polar Record, 45 (233): 119-132.

Grosz, E. 2002. A Politics of Imperceptibility: A Response to 'Anti-Racism, Multiculturalism and the Ethics of Identification.' In Philosophy \& Social Criticism, 28 (4): 463-472.

Grosz, E. 2005. Time Travels. Feminism, Nature, Power. Durham, Nc: Duke University Press.

Guthman, J. 2008. Neoliberalism and the Making of Food Politics in California. In Geoforum, 39: 1171-1183.

Haggerty, K. D., Ericson, R. V. 2000. The Surveillant Assemblage. In The British Journal of Sociology, 51 (4): 605-622.

Hayes-Conroy, A., Hayes-Conroy, J. 2008. Taking Back Taste: Feminism, Food and Visceral Politics. In Gender, Place and Culture, 15 (5): 461-473.

Hayes-Conroy, A., Martin, D. 2010. Mobilising Bodies: Visceral Identification in The Slow Food Movement. Transaction of the Institute of British Geographers, 35: 269281.

Health Canada. 2010. Eating Well With Canada's Food Guide-First Nations, Inuit, and Métis. [online], <http://www.hc-sc.gc.ca/fn-an/pubs/fnim-pnim/index-eng. php>

Hier, S. P. 2003. Probing the Surveillant Assemblage: On the Dialectics of Surveillance Practices as Processes. In Surveillance \& Society, 1 (3): 400-411.

Hopping, B.N., Erber, E., Mead, E., Sheehy, T., Roache, C. Sharma, S. 2010. Socioeconomic Indicators and Frequency of Traditional Food, Junk Food, and Fruit and Vegetable Consumption Amongst Inuit Adults in the Canadian Arctic. In J. Hum. Nutr. Diet, 23 (Suppl. 1): 51-58. 
Igloliorte, H. N.D. We Were so Far Away: The Inuit Experience of Residential Schools. [Curatorial Text/Timeline.] Ottawa, On: Legacy of Hope Foundation With Aboriginal Healing Foundation \& Library and Archives Canada.

James, C. E. 2005. Introduction: Perspectives on Multiculturalism in Canada. In James, C.E. (Ed.). Possibilities and Limitations: Multicultural Policies and Programs in Canada. Halifax, Ns: Fernwood, 12-20.

Jiwani, Y. 2006. Discourses of Denial: Mediations of Race, Gender, and Violence. Vancouver, Bc: Ubc Press.

Johansen, B.E. 2002. The Inuit's Struggle with Dioxins and Other Organic Pollutants. In American Indian Quarterly, 26 (3): 479-490.

Kativik Regional Government. 1990. Games for Children O -5: Development Profiles and Activity Cards. Kuujjuaq, Qc: Author.

Kativik Regional Government. 2006. The Nunavik Nutrition Project in Child Care Centres. Powerpoint Presentation. December 8, 2006.

Kingfisher, C. 2002. The Big Picture: Globalization, Neoliberalism, and the Feminization of Poverty. In Kingfisher, C (Ed.). Western Welfare in Decline: Globalization and Women's Poverty. Philadelphia, Pa: University of Pennsylvania Press, 3-61.

Lee, R. L. M. 2010. On the Margins of Belonging. In Journal of Sociology, 46 (2): 169186.

Lenz Taguchi, H. 2009. Going Beyond the Theory/Practice Divide in Early Childhood Education: Introducing an Intra-Active Pedagogy. New York: Routledge.

Lipski, E. 2010. Traditional Non-Western Diets. Nutrition In Clinical Practice, 25: 585593.

Makivik Corporation. 2008. Canada-Nunavik People. [online], <http://www.classbrain.com/art_cr/publish/canada_nunavik_people.shtml>

Malins, P. 2004. Machinic Assemblages: Deleuze, Guattari and an Ethico-Aesthetics of Drug Use. In Janus Head, 7 (1): 84-104.

Mar, P., Anderson, K. 2010. The Creative Assemblage. In Journal of Cultural Economy, 3(1): 35-51.

Marcus, G. E., Saka, E. 2006. Assemblage. In Theory, Culture \& Society, 23 (2-3): 101-106.

Meis Mason, A., Dana L.P., Anderson, R.B. 2007. The Inuit Commercial Caribou Harvest and Related Agri-Food Industries in Nunavut. In International Journal of Entrepreneurship and Small Business, 4 (6): 785-806.

Michelsen, N. 2009. Addressing the Schizophrenia of Global Jihad. In Critical Studies on Terrorism, 2 (3): 453-471.

Miller, A. 1983. For Our Own Good: Hidden Cruelty in Child Rearing and the Roots of Violence. New York, NY: Farar, Staruss, \& Giroux.

Nolin, B., Lamontagne, P., Tremblay, A. 2007. Nunavik Inuit Health Survey 2004, Quanuipptaa? How are We? Physical Activity, Anthropometry and Perception of Body Weight. Québec, QC: Nunavik Regional Board of Health and Social Services. 
Olsson, L. 2009. Movement and Experimentation in Young Children's Learning: Deleuze and Guattari in Early Childhood Education. New York: Routledge.

O’Neill, J. 1977, May 5. Opposition Fails to Halt Native Land Bill. Ottawa Citizen.

Ong, A. 2007. Neoliberalism as a Mobile Technology. In Transactions of the Institute of British Geographers, 32 (1): 3-8.

Pacini-Ketchabaw, V. 2007. Child Care and Multiculturalism: A Site of Governance Marked by Flexibility and Openness. In Contemporary Issues In Early Childhood, 8 (3): 222-232.

Patton, P. 1994. Metamorphologic: Bodies and Powers in a Thousand Plateaus. In Journal of the British Society for Phenomenology, 25 (2): 157-69.

Prince, R. 2010. Policy Transfer as Policy Assemblage: Making Policy for the Creative Industries in New Zealand. In Environment and Planning A, 42 (1): 169-186.

Probyn, E. 2001. Carnal Appetites: Food Sex Identities. New York, NY: Routledge.

Puttayuk, A. 2008. Caribou. Montréal, QC: Avataq Cultural Institute.

Read, J. 2009. A Genealogy of Homo-Economicus: Neoliberalism and the Production of Subjectivity. In Foucault Studies, 6: 25-36.

Roberts, D. J., Mahtani, M. 2010. Neoliberalizing Race, Racing Neoliberalism: Placing "Race" in Neoliberal Discourses. In Antipode, 42 (2): 248-257.

Rowan, M.C. 2003. Report Concerning the Review and Proposed Revision of Childcare Regulations for the Inuit Communities of Northern Labrador. Prepared for the Labrador Inuit Health Commission.

Rowan, M.C. 2011. Exploring the Possibilities of Learning Stories as a Meaningful Approach to Assessment in Nunavik. Unpublished Masters Thesis. University of Victoria, British Columbia, Canada.

Ruffolo, D. V. 2009. Queering Child/Hood Policies: Canadian Examples and Perspectives. In Contemporary Issues in Early Childhood, 10 (3): 291-308.

Saldanha, A. 2006. Reontologising Race: The Machinic Geography of Phenotype. In Environment and Planning D, 24 (1): 9-24.

Schwarz, B. 2000. Becoming Postcolonial. In Gilroy, P., Grossberg, L., Mcrobbie, A (Eds.), Without Guarantees: In Honour of Stuart Hall. London, UK: Verso, 268-281.

Shire, G. 2008. Race In Neoliberal Times.In Soundings, 38: 70-81.

Simon, M. 2011. Inuit and Social Justice. Talk Given at Ryerson University, Toronto, Ontario, May 24, 2011. [online], <http://www.itk.ca/media-centre/speeches/inuitand-social-justice-ryerson-university-toronto-ontario-may-24-2011>

Slocum, R. 2008. Thinking Race Through Corporeal Feminist Theory: Divisions and Intimacies at the Minneapolis Farmers' Market. In Social \& Cultural Geography, 9 (8): 849-869.

Slocum, R. 2011. Race in the Study of Food. In Progress In Human Geography, 35 (3): 303-327.

Statistics Canada. 2006. High School Completion Rates. Census of Population. Statistics Canada Catalogue No. 97-560-XCB2006036. 
Statistics Canada 2008. Aboriginal People's Survey. [online], <http://www.statcan. gc.ca>

Stewart, K. 2007. Ordinary Affects. Durham, NC: Duke University Press.

Stoler, A.L. 1995. Race and the Education of Desire: Foucault's History of Sexuality and the Colonial Order of Things. Durham, NC: Duke University Press.

Stoler, A.L. 2008. Imperial Debris: Reflections on Ruins and Ruination. In Cultural Anthropology, 23 (2): 191-219.

Subedi, B., Daza, S.L. 2008. The Possibilities of Postcolonial Praxis in Education. In Race, Ethnicity, and Education, 11 (1): 1-10.

Swadener, B. B., Mutua, K. 2008. Decolonizing Performances: Deconstructing the Global Postcolonial. In Denzin, N. K., Lincoln, Y. S. Smith, L. T. (Eds.), Handbook of Critical Indigenous Methodologies. Thousand Oaks, CA: Sage, 31-43.

Tagataga Inc. 2007. Inuit Early Education and Care: Present Successes, Promising Directions. A Discussion Paper for the National Inuit Education Summit. Ottawa, ON: Inuit Tapiriit Kanatami.

Taqulik, L. 2008. Annie's Ulu. Montréal, QC: Avataq Cultural Institute.

Whatmore, S. 2002. Hybrid Geographies: Natures, Cultures, Spaces. London, UK: Sage.

Whatmore, S. 2006. Materialist Returns: Practising Cultural Geographies in and for a More-Than-Human World. In Cultural Geographies, 13 (4): 600-610.

Willett, W. C., Stampfer, M. J. 2003. Rebuilding the Food Pyramid. In Scientific American, 288 (1): 64-71.

Willows, N.D. 2005, July/August. Determinants of Healthy Eating in Aboriginal Peoples in Canada: The Current State of Knowledge and Research Gaps. In Canadian Journal of Public Health, S32-S36.

\section{Authors:}

Fikile Nxumalo

Veronica Pacini-Ketchabaw, Ph.D., Associate Professor

Mary Caroline Rowan

University of Victoria

School of Child and Youth Care

PO Box 1700 STN CSC, Victoria

British Columbia

Canada V8W 2Y2

Email: fnxumalo@uvic.ca; vpacinik@uvic.ca; carol.rowan@unb.ca 